\title{
THE INFLUENCE OF THE HORIZONTAL REDISTRIBUTION MECHANISM UNDER THE GENERAL SUBSIDY UPON THE FINANCIAL SITUATION OF VOIVODESHIPS IN POLAND ï STUDY RESULTS
}

\section{JarosĞaw OLEJNICZAK, Ph.D.}

\author{
Department of Finance \\ Faculty of Economic Sciences \\ Wroclaw University of Economics \\ $\triangle$ Komandorska street 118/120, 53-345 Wroclaw, Poland \\ E-mail: jaroslaw.olejniczak@ue.wroc.pl
}

\begin{abstract}
Annotation
The main objective of this paper was to conduct the analysis and the assessment of the significance of a equalisation and regional part of the general subsidy for the voivodeships in Poland. The study procedure encompass the analysis of the horizontal redistribution scale in the all 16 regions in Poland, the analysis of the financial situation of the voivodeships in the years 2008-2012, using the databases of the Ministry of Finances, and also the comparative analysis of initial indicators and the corrected indicators obtained as a result of excluding income streams resulting from the equalisation mechanism. Therefore, for the better understanding the importance of the subsidy redistribution mechanism, it was necessary to reduce the calculation elements of the indicators by their value. In the majority of cases omitting the subsidy in the calculation resulted in the deterioration of the budgetary indicators in the half of voivodeships. It should be noticed that in the most extreme cases, the volume of subventions received was as much as twice the size of own revenue. This may attest to the striking maladjustment between the structure of regional income and the regional financing demands. It must be also noted that the outflow of proceeds under the pending óRobin Hood taxôregulations $і$ in the case of the Mazovian Voivodship(mazowieckie) ï reached as much as a third of regional revenue, overall. This has the effect of greatly reducing the level of financing available for self-governing regions. In the Mazovian Voivodeship, the adopted fiscal solution resulted in liquidity loss.
\end{abstract}

\section{Key words}

equalisation, regional self-government budget, Robin Hood Tax

JEL classification: $H 2, H 7$

\section{Introduction}

The second stage of public finance decentralisation in Poland, introduced in 1998, established the legal framework of territorial self-government administration at voivodeship level. The new legislation determined the distribution of competences between regional bodies of state administration, represented by voivodes (regional governors), and those of regional self-government administration $\ddot{i}$ the assembly and the regional executive board. Regional self-government bodies are responsible for the proprietary tasks as formulation of regional development strategies, implementation of regional development strategies, public education, including higher education, health promotion and protection, culture and protection of cultural heritage, welfare policy, modernization of rural areas, spatial development, water management, regional roads and transportation, countering the unemployment. 
The use of the term q́roprietary taskôstipulates that the voivodeship is the sole executor of the tasks presented above, with the power to decide on the manner of execution, and held responsible for their proper realization. At the region (voivodeship) level, the activities undertaken in the areas defined in the Act (Act on the Regional Self-Government) may go beyond the territorial boundaries of individual districts (poviats - the second level of local government administration). It should be noted that the above tasks are defined in the respective legislative decisions that specify the legal framework of administration in the aforementioned areas. Thus, in general, it may be observed that regional self-government is, first and foremost, responsible for interregional and transfrontier relations. At the same time, regional self-government bodies are responsible for the realization of tasks conferred to them by the respective legislative regulations of central administration, such as the management and maintenance of geodesic and cartographic repositories etc. They are also authorised to negotiate and perform other tasks, at the behest of the regional governor or other territorial selfadministration units.

The 1998 reform of the territorial administration system was, undeniably, influenced by the intent to continue the adopted public finance decentralisation approach, with the main emphasis on supporting the independence of regional self-administration bodies. In this context, the independence is defined as: the ability to autonomously decide on the regional budget, with the corresponding set of responsibilities; or the ability to make autonomous decisions with respect to the objectives, the manner and the volume of public purse expenditures, within the limits set down for the region; or the ability to decide on their income structure.

\section{The objective and study method}

The essential objective of this paper is finding an answer to the question, whether in the case of voivodeships in Poland horizontal redistribution mechanism constitutes a significant support for their financial management. Therefore, to answer the above question, it will be important, first of all, to conduct the analysis of the development of basic budgetary indicators describing financial management the voivodeships in the years 2008-2012 (the data of the Ministry of Finances); second of all, it is important to analyse the influence of the equalisation mechanism being part of the general subsidy upon the formation of the above-mentioned indicators (data of the National Statistic Office). The result of the above-mentioned analyses will be an answer to the question, whether in the case of the all regions in Poland, the equalisation mechanism inherent to the general subsidy exerts a significant influence upon their financial management. Indirectly, it will constitute an answer to the question concerning the necessity and usefulness of the existence of the horizontal redistribution mechanism in voivodeships.

The study procedure will encompass the analysis of the horizontal redistribution scale in the all 16 regions in Poland, the analysis of the financial situation of the voivodeships in the years 2008-2012, using the databases of the Ministry of Finances, and also the comparative analysis of initial indicators and the corrected indicators obtained as a result of excluding income streams resulting from the equalisation mechanism.

\section{Main theoretical and law issues}

\section{A. Budgetary indicators used for the assessment of the financial condition of self- government (Olejniczak, 2014).}

In order to make it possible to conduct the comparison of financial situation of the units of territorial self-government, the Ministry of Finances presents a set of indicators calculated for the units of territorial self-government every year. The group of budgetary indicators includes seven indicators, describing mainly the general structure (current, on property and proprietary) of revenues and expenses (Ministry of Finance). Among the budgetary indicators analysed in this paper, we include, first of all, the indicator $\quad \ddot{i}$ expressing the share of current yields in total revenues. 


$$
=-(1)
$$

Where: $\operatorname{Tr} \ddot{\mathrm{I}}$ total revenues, $C y \ddot{~} \mathrm{i}$ current yields (revenues not belonging to the category of proprietary revenues).

shows what part of total revenues is constituted by current yields. It should be pointed out that it is nothing else, but the level of current yields that the scale and the scope of the tasks performed by a self-government depends. The reason for that fact is the general principle set forth in The Act on Public Finances, namely that the current expenses of a self-government should not exceed the level of its current yields. The act stipulates that so-called operational deficit is no permitted under the act in question. Correction by the size of equalization elements of the subsidy (S) makes it possible to answer the question, concerning the impact of the subsidy mechanism upon the level of revenues ï to what degree, equalisation and balancing part of the subsidy exert influence upon increasing the possibilities of financing current expenses in the regions. The corrected will, therefore, have the following value:

$$
=-(2)
$$

Next indicator proposed by the Ministry of Finances is $C_{\mathrm{e} 2} \ddot{\mathrm{i}}$ expressing the share of proprietary revenues in total revenues. It shows what part of the total revenues ( $\mathrm{Tr}$ ) is constituted by proprietary revenues (Pr), which means, therefore, revenues excluding, among others, subsidies and grants. Amounts contributing to the budgets of self-government from the two parts of the subsidy discussed before may significantly olleteriorate8the state of the revenue independence of regions, and the reason for that fact is that they exert influence upon increase in the level of revenue in general. Separating the subsidies from the total amount of revenues should make it possible to achieve the better comparability of financial data between regions and their actual level of self-financing.

$$
=-(3)
$$

The corrected indicator will, in turn, have the following form

$$
=-(4)
$$

Another discussed indicator is $\mathrm{Ce} 3 \mathrm{i}$ reflecting the share of operating surplus in total revenues. Operating surplus is the positive result of comparing current yields $\left(\mathrm{C}_{\mathrm{y}}\right)$ with current expenses $\left(\mathrm{C}_{\mathrm{e}}\right)$.

$$
=-(5)
$$

Operating surplus indicates the potential abilities and possibilities of a unit of territorial selfgovernment in terms of meeting its liabilities, and also of financing investment expenses. The share of operating surplus in total revenues $\left(C_{\mathrm{e} 3}\right)$ determines the degree to which a unit could incur new liabilities in relation to the actual revenues. Correcting this indicator by the value of equalisation and regional part will make this indicator show the actual ability of a voivodeship in terms of meeting its liabilities. The modified equation will, therefore, be as follows:

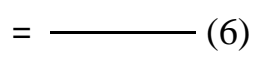

Nextr one of the analysed indicators is $\mathrm{C}_{\mathrm{e} 6}$. It reflects the share of and income from property sale $\left(\mathrm{P}_{\mathrm{s}}\right)$ in total revenues. The higher value of this indicator in comparison with the previous one $\left(\mathrm{C}_{\mathrm{e} 3}\right)$ proves that a voivodeship, apart from generating a positive result, has also obtained additional revenues from property sale. This indicator may be expressed in the following form: 


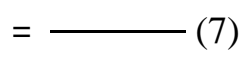

In turn, the corrected indicator will have the following form:

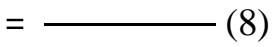

The last one of indicators is so-called self-financing indicator $\left(\mathrm{C}_{\mathrm{e} 7}\right)$, being the proportion of the sum of operating surplus and property revenues $\left(\mathrm{P}_{\mathrm{r}}\right)$ to expenses on property $\left(\mathrm{P}_{\mathrm{e}}\right)$. The value of it shows the degree to which a voivodeship finances its investments with the use of its own means. The higher this proportion is, the smaller the risk of losing financial liquidity in connection with the excessive debt service costs, however, the high value of it may also prove a low level of the implemented investments in proportion to its own possibilities. It may be expressed in the following way:

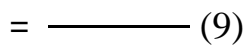

In turn, after correcting by the value of equalisation and regional part of the subsidy, it will have the following form:

$=\longrightarrow(10)$

\section{B. Regions revenues ï equalisation part}

The problem of providing the regions with revenue adequate to the tasks delegated to them is of particular importance in the context of financial independence. In accordance with the recommendations presented in art. 14) of draft European Charter of Regional Self-Government, adopted at the $4^{\text {th }}$ session of the Congress of Local and Regional Authorities of Europe (Strasbourg, 35 June 1997), the funding system for the regions shall provide them with a foreseeable amount of revenue commensurate with their competences and allowing them to conduct their own policies.

The self-government voivodship authorities in Poland have limited sources of own revenue. These include, among others: proceeds from regional budget entities, payments from regional budget organizations, proceeds from regional assets, bequests, endowments, donations, proceeds from fines and other financial measures imposed by law, and other. But the main financing sources for regions come in the form of share in the income tax revenues levied from natural persons registered as residents in the region and established at $1.60 \%$, and the share in the income tax revenues levied from legal persons residing in the region $і ̈$ established at $14.75 \%$ of total revenue.

Consequently, as suggested by the above, the self-government voivodship authorities have little influence over their income levels. This raised the necessity to provide some statutory system for supplementary financing, in the form of equalisation subventions and regional subventions (Act on the Revenues of the Units of Territorial Self-government).

The equalisation part of the general subvention is designed to level the disproportions of income potential between regions. It is defined as sum of basic quota and supplementing quota. The basic quota is granted to those voivodships where the tax revenue index per capita $(\mathrm{W})$ is found below the level calculated for all regions (Ww). The amount of basic quota due is calculated as $72 \%$ of the difference between $\mathrm{Ww}$ and $\mathrm{W}$ indexes multiplied by the number of the regionô inhabitants.

The supplementing quota, on the other hand, is received by voivodships with population less than 3 million inhabitants. It is calculated as $9 \%$ of the $\mathrm{Ww}$ index multiplied by the number of inhabitants. The population count, in this approach, is calculated regressively $i$ the higher the population, the lower is the associated increase of population level. 
The second part of the general subvention $\ddot{i}$ the regional subvention $\ddot{i}$ is determined as the sum of payments collected from voivodships under the so called ñRobin Hood taxò This particular taxation mechanism applies to regions with $\mathrm{W}$ index surpassing the $110 \%$ of the $\mathrm{Ww}$ index, and the amount due is calculated as the product of the regionôs population count by $80 \%$ of the surplus of $\mathrm{W}$ index over the $110 \%$ of the Ww index $\ddot{i}$ for regions with $\mathrm{W}$ found no higher than $170 \%$ of the $\mathrm{Ww}$ index $\ddot{i}$ or as $48 \%$ of the $\mathrm{Ww}$ index, supplemented by $95 \%$ of the surplus of $\mathrm{W}$ index over the $170 \%$ of the $\mathrm{Ww}$ index $\ddot{i}$ for regions with $\mathrm{W}$ found in excess of the $170 \%$ of the $\mathrm{Ww}$ index.

The resulting quota is then divided into the following: $20 \%$ between regions with unemployment level found below $110 \%$ of the mean national unemployment rate; $40 \%$ between regions with regional road area per region inhabitant found in excess of the mean national per capita level; $10 \%$ between regions with GDP per inhabitant lower than $75 \%$ of the national GDP per capita; $15 \%$ between regions based on reported levels of expenditure on regional rail passenger transportation for the previous year; $15 \%$ between regions where planned revenue from equalisation part and from regional part of general subvention per budget year, adjusted by planned state budget contribution, is lower than the corresponding value calculated per base year.

\section{Survey results}

The significance of horizontal equalisation of financial resources between self-governing regions is best illustrated in the correlation between the volume of financing and the volume of own proceeds in individual regions. The reported figures show the colossal effects of state subventions in five of the sixteen voivodeships. In the most extreme cases, the volume of subventions received was as much as twice the size of own revenue. This may attest to the striking maladjustment between the structure of regional income and the regional financing demands. At the same time, it must be noted that the outflow of proceeds under the pending đ́Robin Hood taxôregulations $i ̈$ in the case of the Mazovian Voivodship $і ̈$ reached as much as a third of regional revenue, overall. This has the effect of greatly reducing the level of financing available for self-governing regions. In the Mazovian Voivodeship, the adopted fiscal solution resulted in liquidity loss. Consequently, the present administrative regulations will be revised by 2016 by the power of Constitutional Tribunal decision, in order to satisfy the financial demands of those regions which at present are the net payers of the ớobin Hood taxô

Tab. 1: The correlation between the volume of financing and the volume of own proceeds

\begin{tabular}{|c|c|c|c|c|c|}
\hline$x^{2}$ & 2008 & 2009 & 2010 & 2011 & 2012 \\
\hline DolnoŜńkkie & $9,6 \%$ & $11,5 \%$ & $11,6 \%$ & $9,7 \%$ & $5,1 \%$ \\
\hline Kujawsko-pomorskie & $54,0 \%$ & $78,0 \%$ & $93,4 \%$ & $67,7 \%$ & $60,6 \%$ \\
\hline Lubelskie & $77,6 \%$ & $117,6 \%$ & $176,1 \%$ & $111,1 \%$ & $98,5 \%$ \\
\hline Lubuskie & $68,0 \%$ & $80,7 \%$ & $98,7 \%$ & $70,7 \%$ & $95,7 \%$ \\
\hline Ğódzkie & $26,0 \%$ & $32,5 \%$ & $35,7 \%$ & $22,5 \%$ & $16,8 \%$ \\
\hline Mağpolskie & $15,3 \%$ & $20,7 \%$ & $22,4 \%$ & $13,5 \%$ & $19,3 \%$ \\
\hline Mazowieckie & $-28,7 \%$ & $-36,3 \%$ & $-46,3 \%$ & $-34,1 \%$ & $-36,2 \%$ \\
\hline Opolskie & $36,2 \%$ & $62,3 \%$ & $87,4 \%$ & $56,2 \%$ & $68,1 \%$ \\
\hline Podkarpackie & $82,5 \%$ & $103,9 \%$ & $162,6 \%$ & $100,1 \%$ & $115,4 \%$ \\
\hline Podlaskie & $67,4 \%$ & $94,9 \%$ & $148,3 \%$ & $106,3 \%$ & $124,5 \%$ \\
\hline pomorskie & $16,3 \%$ & $25,0 \%$ & $26,8 \%$ & $19,9 \%$ & $16,2 \%$ \\
\hline ślŃkkie & $3,2 \%$ & $10,0 \%$ & $9,7 \%$ & $12,0 \%$ & $7,8 \%$ \\
\hline Świňtokrzyskie & $52,7 \%$ & $82,5 \%$ & $99,4 \%$ & $64,3 \%$ & $88,4 \%$ \\
\hline Warmiণkko-mazurskie & $77,1 \%$ & $129,3 \%$ & $162,7 \%$ & $118,8 \%$ & $119,6 \%$ \\
\hline Wielkopolskie & $5,5 \%$ & $8,1 \%$ & $9,8 \%$ & $4,6 \%$ & $5,3 \%$ \\
\hline Zachodniopomorskie & $55,5 \%$ & $79,3 \%$ & $102,2 \%$ & $67,7 \%$ & $64,6 \%$ \\
\hline
\end{tabular}

Source: Own calculations based on MF (Ministry of Finance) data

The volumes presented in table 2 show explicitly that, for some regions, the equalisation mechanism is an invaluable source of financing. As many as seven out of the sixteen Polish regions report their adjusted indicators of the share of current yields in total revenues $\left(\mathrm{C}_{\mathrm{els}}\right)$ to be lower by ca. 10 percentage points. This suggests that horizontal equalisation in those regions has the effect of 
significantly improving their ability to perform the current tasks delegated to them. It must also be noted that the significance of the equalization mechanism has grown steadily since the early months of the recent financial crisis, as attested by the noticeable increase of the difference between the base and the adjusted indicators. In the case of the Mazovian Voivodship, the lack of significant adjustment of the indicator may be attributed to the fact that the region is a net payer of the Robin Hood tax, while the adjustment applies solely to the relative quotas of the regional part of the subventions.

Tab. 2: The share of current yields in total regions revenues

\begin{tabular}{|c|c|c|c|c|c|c|c|c|c|c|}
\hline \multirow[t]{2}{*}{ Region } & \multicolumn{5}{|c|}{$C_{e l}$} & \multicolumn{5}{|c|}{$C_{e l s}$} \\
\hline & 2008 & 2009 & 2010 & 2011 & 2012 & 2008 & 2009 & 2010 & 2011 & 2012 \\
\hline DolnoŜŃkie & $87,00 \%$ & $60,90 \%$ & $83,90 \%$ & $80,60 \%$ & $74,40 \%$ & $86,1 \%$ & $59,2 \%$ & $82,9 \%$ & $79,6 \%$ & $73,7 \%$ \\
\hline Kujawsko-pomorskie & $88,30 \%$ & $68,60 \%$ & $70,70 \%$ & $81,70 \%$ & $83,30 \%$ & $84,8 \%$ & $61,5 \%$ & $62,7 \%$ & $77,0 \%$ & $79,3 \%$ \\
\hline Lubelskie & $87,50 \%$ & $72,10 \%$ & $79,80 \%$ & $71,80 \%$ & $78,50 \%$ & $82,4 \%$ & $62,6 \%$ & $68,0 \%$ & $62,4 \%$ & $71,0 \%$ \\
\hline Lubuskie & $83,30 \%$ & $46,10 \%$ & $68,10 \%$ & $71,10 \%$ & $77,40 \%$ & $77,4 \%$ & $37,2 \%$ & $56,9 \%$ & $63,1 \%$ & $70,5 \%$ \\
\hline Ğódzkie & $88,70 \%$ & $54,30 \%$ & $79,10 \%$ & $75,00 \%$ & $71,80 \%$ & $86,8 \%$ & $50,2 \%$ & $75,3 \%$ & $72,2 \%$ & $69,6 \%$ \\
\hline Mağpolskie & $81,50 \%$ & $56,50 \%$ & $60,90 \%$ & $60,70 \%$ & $70,30 \%$ & $79,7 \%$ & $53,5 \%$ & $57,8 \%$ & $58,4 \%$ & $67,9 \%$ \\
\hline Mazowieckie & $95,40 \%$ & $86,50 \%$ & $85,80 \%$ & $84,80 \%$ & $87,00 \%$ & $95,2 \%$ & $85,8 \%$ & $84,9 \%$ & $84,7 \%$ & $86,8 \%$ \\
\hline Opolskie & $70,90 \%$ & $54,70 \%$ & $61,90 \%$ & $63,30 \%$ & $75,80 \%$ & $65,3 \%$ & $47,9 \%$ & $52,9 \%$ & $56,2 \%$ & $70,2 \%$ \\
\hline Podkarpackie & $86,40 \%$ & $74,90 \%$ & $76,30 \%$ & $72,80 \%$ & $74,70 \%$ & $80,9 \%$ & $67,1 \%$ & $65,3 \%$ & $63,3 \%$ & $65,8 \%$ \\
\hline Podlaskie & $84,80 \%$ & $57,70 \%$ & $77,90 \%$ & $70,70 \%$ & $72,00 \%$ & $79,4 \%$ & $48,2 \%$ & $67,3 \%$ & $61,7 \%$ & $62,9 \%$ \\
\hline pomorskie & $78,60 \%$ & $53,90 \%$ & $77,60 \%$ & $73,30 \%$ & $70,10 \%$ & $76,4 \%$ & $50,6 \%$ & $74,5 \%$ & $70,6 \%$ & $67,7 \%$ \\
\hline ŚlŃkkie & $85,40 \%$ & $67,80 \%$ & $70,70 \%$ & $82,10 \%$ & $77,50 \%$ & $85,1 \%$ & $66,6 \%$ & $69,2 \%$ & $80,8 \%$ & $76,6 \%$ \\
\hline Świňtokrzyskie & $88,40 \%$ & $64,40 \%$ & $70,50 \%$ & $70,80 \%$ & $61,60 \%$ & $84,9 \%$ & $56,8 \%$ & $59,9 \%$ & $63,4 \%$ & $51,8 \%$ \\
\hline WarmiCkko-mazurskie & $83,90 \%$ & $65,50 \%$ & $85,20 \%$ & $75,10 \%$ & $70,50 \%$ & $77,5 \%$ & $56,5 \%$ & $76,5 \%$ & $65,0 \%$ & $60,2 \%$ \\
\hline Wielkopolskie & $88,30 \%$ & $47,60 \%$ & $72,40 \%$ & $68,80 \%$ & $76,20 \%$ & $87,8 \%$ & $46,4 \%$ & $71,0 \%$ & $68,1 \%$ & $75,6 \%$ \\
\hline Zachodniopomorskie & $86,00 \%$ & $52,80 \%$ & $63,00 \%$ & $65,20 \%$ & $63,20 \%$ & $81,7 \%$ & $45,2 \%$ & $51,9 \%$ & $57,2 \%$ & $55,3 \%$ \\
\hline
\end{tabular}

Source: Own calculations based on MF (Ministry of Finance) and NSO(National Statistical Office) data

With respect to the second indicator $\ddot{i}$ the share of proprietary revenues in total revenues $\left(\mathrm{C}_{\mathrm{e} 2 \mathrm{~s}}\right) \ddot{i}$ it can be observed that regions reported increases in their financial independence indicators after deducting the redistribution elements of the regional subvention quota (table 3). For some regions, this increase was as much as 10 p.p. This means that, after considering the share of subvention in total revenues, and depending on the volume of subventions received (which are, in part, unrelated to the regionôs revenues, since their volume may also be related to infrastructural indicators), there will be significant differences between individual regions, even if they report similar levels of proprietary revenues. This may have a negative effect on the comparability of the regionsôrevenue potential calculated using the above indicators. Also in this respect, the Mazovian Voivodship reported ca. 3 p.p increase of the indicator, based on their share of the regional part of the subvention received.

Tab. 3: The share of proprietary revenues in regions total revenues

\begin{tabular}{|c|c|c|c|c|c|c|c|c|c|c|}
\hline \multirow[t]{2}{*}{ Region } & \multicolumn{5}{|c|}{$C_{e 2}$} & \multicolumn{5}{|c|}{$C_{e 2 s}$} \\
\hline & 2008 & 2009 & 2010 & 2011 & 2012 & 2008 & 2009 & 2010 & 2011 & 2012 \\
\hline DolnoŜŃkkie & $67,90 \%$ & $36,30 \%$ & $52,40 \%$ & $52,00 \%$ & $54,90 \%$ & $72,6 \%$ & $37,9 \%$ & $55,8 \%$ & $54,7 \%$ & $56,5 \%$ \\
\hline Kujawsko-pomorskie & $42,90 \%$ & $23,60 \%$ & $23,00 \%$ & $30,00 \%$ & $31,80 \%$ & $55,8 \%$ & $29,0 \%$ & $29,2 \%$ & $37,7 \%$ & $39,4 \%$ \\
\hline Lubelskie & $37,20 \%$ & $21,70 \%$ & $21,00 \%$ & $22,60 \%$ & $26,30 \%$ & $52,3 \%$ & $29,1 \%$ & $33,3 \%$ & $30,2 \%$ & $35,4 \%$ \\
\hline Lubuskie & $38,40 \%$ & $17,40 \%$ & $26,40 \%$ & $30,60 \%$ & $24,40 \%$ & $51,9 \%$ & $20,3 \%$ & $35,7 \%$ & $39,0 \%$ & $31,9 \%$ \\
\hline Ğódzkie & $57,00 \%$ & $25,80 \%$ & $43,00 \%$ & $44,30 \%$ & $43,40 \%$ & $66,9 \%$ & $28,1 \%$ & $50,7 \%$ & $49,3 \%$ & $46,8 \%$ \\
\hline Mağpolskie & $58,90 \%$ & $31,20 \%$ & $32,90 \%$ & $40,10 \%$ & $38,30 \%$ & $64,7 \%$ & $33,3 \%$ & $35,6 \%$ & $42,4 \%$ & $41,3 \%$ \\
\hline Mazowieckie & $83,40 \%$ & $67,10 \%$ & $69,30 \%$ & $72,60 \%$ & $69,60 \%$ & $86,62 \%$ & $70,86 \%$ & $73,93 \%$ & $73,15 \%$ & $70,49 \%$ \\
\hline Opolskie & $44,30 \%$ & $21,00 \%$ & $21,80 \%$ & $28,70 \%$ & $27,90 \%$ & $52,8 \%$ & $24,2 \%$ & $26,9 \%$ & $34,2 \%$ & $34,4 \%$ \\
\hline Podkarpackie & $35,20 \%$ & $22,70 \%$ & $19,50 \%$ & $25,90 \%$ & $22,70 \%$ & $49,6 \%$ & $29,7 \%$ & $28,6 \%$ & $35,0 \%$ & $30,8 \%$ \\
\hline Podlaskie & $38,80 \%$ & $19,50 \%$ & $21,90 \%$ & $22,10 \%$ & $19,70 \%$ & $52,6 \%$ & $23,9 \%$ & $32,4 \%$ & $28,8 \%$ & $26,1 \%$ \\
\hline pomorskie & $56,10 \%$ & $27,20 \%$ & $45,30 \%$ & $46,70 \%$ & $46,70 \%$ & $61,8 \%$ & $29,2 \%$ & $51,5 \%$ & $51,4 \%$ & $50,5 \%$ \\
\hline ślŃkkie & $66,60 \%$ & $37,10 \%$ & $48,90 \%$ & $55,30 \%$ & $51,10 \%$ & $68,0 \%$ & $38,6 \%$ & $51,3 \%$ & $59,3 \%$ & $53,2 \%$ \\
\hline Świňtokrzyskie & $43,60 \%$ & $21,30 \%$ & $26,40 \%$ & $31,50 \%$ & $23,00 \%$ & $56,6 \%$ & $25,8 \%$ & $35,9 \%$ & $39,5 \%$ & $28,9 \%$ \\
\hline Warmiণkko-mazurskie & $36,50 \%$ & $16,00 \%$ & $22,60 \%$ & $24,30 \%$ & $21,50 \%$ & $50,8 \%$ & $20,1 \%$ & $35,8 \%$ & $34,1 \%$ & $29,0 \%$ \\
\hline Wielkopolskie & $65,80 \%$ & $28,90 \%$ & $49,40 \%$ & $52,60 \%$ & $48,70 \%$ & $68,3 \%$ & $29,6 \%$ & $51,9 \%$ & $53,9 \%$ & $50,0 \%$ \\
\hline Zachodniopomorskie & $42,60 \%$ & $17,50 \%$ & $22,60 \%$ & $27,70 \%$ & $27,20 \%$ & $55,8 \%$ & $20,3 \%$ & $29,4 \%$ & $34,1 \%$ & $33,0 \%$ \\
\hline
\end{tabular}

Source: Own calculations based on MF (Ministry of Finance) and NSO (National Statistical Office) data 
In the case of the indicator reflecting the share of operating surplus in total revenues $\mathrm{C}_{\mathrm{e} 3}$, the adjustment suggests that more than a half of Polish regions are unable to generate any surplus whatsoever, and have no potential to meet their liabilities on their own (table 4). In the case of the Mazovian Voivodship as the (usually) sole example of a net payer of both the regional and the compensatory part, it must be observed that the respective indicator will be elevated (for this particular region, total revenues are not adjusted against total fiscal contribution, but only against the regional part of the subvention). Similar adjustments were observed for Lower Silesia (dolnoŜŃkie) and Great Poland (wielkopolskie) in the period when those two regions were net payers of the óRobin Hood taxô but the effect of those payments on the adjusted indicator were marginal. The increase of the self-financing indicator for Mazovia region, reported at times to be even more than 30 p.p., clearly attests to the negative impact of the đ́Robin Hood taxôon the regionôs financial standing. In general, however, it may be concluded that the volumes of adjusted indicators clearly attest to the significance of the equalisation mechanism for less-developed regions.

Tab. 4: The share of operating surplus in regions total revenues

\begin{tabular}{|c|c|c|c|c|c|c|c|c|c|c|}
\hline \multirow[t]{2}{*}{ Region } & \multicolumn{5}{|c|}{$C_{e 3}$} & \multicolumn{5}{|c|}{$C_{e 3 s}$} \\
\hline & 2008 & 2009 & 2010 & 2011 & 2012 & 2008 & 2009 & 2010 & 2011 & 2012 \\
\hline DolnoŜŃkkie & $23,10 \%$ & $7,10 \%$ & $2,50 \%$ & $9,20 \%$ & $21,50 \%$ & $17,8 \%$ & $3,0 \%$ & $-3,8 \%$ & $4,4 \%$ & $19,3 \%$ \\
\hline Kujawsko-pomorskie & $19,20 \%$ & $13,00 \%$ & $6,20 \%$ & $9,80 \%$ & $12,00 \%$ & $-5,1 \%$ & $-6,7 \%$ & $-19,3 \%$ & $-13,2 \%$ & $-9,0 \%$ \\
\hline Lubelskie & $26,30 \%$ & $12,10 \%$ & $13,90 \%$ & $10,70 \%$ & $10,00 \%$ & $-3,6 \%$ & $-18,1 \%$ & $-36,6 \%$ & $-19,3 \%$ & $-21,4 \%$ \\
\hline Lubuskie & $18,00 \%$ & $6,90 \%$ & $8,30 \%$ & $7,30 \%$ & $7,50 \%$ & $-10,9 \%$ & $-8,4 \%$ & $-24,0 \%$ & $-18,3 \%$ & $-20,7 \%$ \\
\hline Gódzkie & $21,90 \%$ & $9,70 \%$ & $15,30 \%$ & $7,90 \%$ & $6,10 \%$ & $8,3 \%$ & $1,5 \%$ & $-0,1 \%$ & $-2,3 \%$ & $-1,3 \%$ \\
\hline Mağpolskie & $27,40 \%$ & $8,90 \%$ & $3,20 \%$ & $9,50 \%$ & $10,60 \%$ & $20,3 \%$ & $2,6 \%$ & $-4,5 \%$ & $4,4 \%$ & $3,5 \%$ \\
\hline Mazowieckie & $20,80 \%$ & $8,30 \%$ & $2,80 \%$ & $5,40 \%$ & $9,50 \%$ & $46,30 \%$ & $34,53 \%$ & $37,19 \%$ & $30,36 \%$ & $35,17 \%$ \\
\hline Opolskie & $11,40 \%$ & $5,10 \%$ & $1,80 \%$ & $1,00 \%$ & $9,30 \%$ & $-5,6 \%$ & $-9,2 \%$ & $-21,3 \%$ & $-18,0 \%$ & $-11,9 \%$ \\
\hline Podkarpackie & $24,00 \%$ & $13,20 \%$ & $15,20 \%$ & $13,90 \%$ & $14,00 \%$ & $-7,2 \%$ & $-13,6 \%$ & $-24,3 \%$ & $-16,2 \%$ & $-16,6 \%$ \\
\hline Podlaskie & $25,90 \%$ & $16,80 \%$ & $19,70 \%$ & $12,90 \%$ & $9,80 \%$ & $-0,3 \%$ & $-2,0 \%$ & $-18,8 \%$ & $-13,8 \%$ & $-19,6 \%$ \\
\hline pomorskie & $22,20 \%$ & $6,40 \%$ & $10,10 \%$ & $13,20 \%$ & $8,30 \%$ & $14,4 \%$ & $-0,4 \%$ & $-2,4 \%$ & $4,4 \%$ & $0,8 \%$ \\
\hline ślŃkkie & $20,70 \%$ & $7,80 \%$ & $15,40 \%$ & $18,50 \%$ & $11,10 \%$ & $19,0 \%$ & $4,3 \%$ & $11,1 \%$ & $12,7 \%$ & $7,4 \%$ \\
\hline Świňtokrzyskie & $37,00 \%$ & $17,90 \%$ & $10,80 \%$ & $13,10 \%$ & $13,60 \%$ & $18,2 \%$ & $0,4 \%$ & $-21,1 \%$ & $-9,0 \%$ & $-8,5 \%$ \\
\hline WarmiCkko-mazurskie & $20,20 \%$ & $6,70 \%$ & $16,90 \%$ & $8,70 \%$ & $9,70 \%$ & $-11,2 \%$ & $-17,6 \%$ & $-31,4 \%$ & $-28,3 \%$ & $-21,6 \%$ \\
\hline Wielkopolskie & $17,20 \%$ & $11,80 \%$ & $13,90 \%$ & $10,90 \%$ & $10,20 \%$ & $14,1 \%$ & $9,7 \%$ & $9,5 \%$ & $8,7 \%$ & $7,8 \%$ \\
\hline Zachodniopomorskie & $21,30 \%$ & $9,40 \%$ & $9,30 \%$ & $8,50 \%$ & $8,10 \%$ & $-3,1 \%$ & $-5,2 \%$ & $-17,9 \%$ & $-12,7 \%$ & $-11,5 \%$ \\
\hline
\end{tabular}

Source: Own calculations based on MF (Ministry of Finance) and NSO (National Statistical Office) data

Another indicator under scrutiny is the share of operational surplus and proceeds from property sale in total revenue. For the whole period under study, the $\mathrm{C}_{\mathrm{e} 6 \mathrm{~s}}$ indicators were higher than the corresponding $\mathrm{C}_{\mathrm{e} 3 \mathrm{~s}}$ indicators only for three of the analysed regions, namely: Mazovia, Silesia(ŜŃkkie) and Great Poland. This may suggest that only those three regions, apart from being able to generate surplus earnings, reported additional profits from sale of their property. In turn, negative values of the indicator (also for the whole period) were reported by 8 regions, suggesting that their proceeds from fixed asset sale were not adequate to cover the operational deficit. It must also be noted that differences between the adjusted indicators $\mathrm{C}_{\mathrm{e} 6 \mathrm{~s}}$ and $\mathrm{C}_{\mathrm{e} 3 \mathrm{~s}}$ were found in surplus of 0.1 p.p. in more than those 3 regions, but were definitely highest for Mazovia (up to 3 p.p.). 
Tab. 5: The self-financing indicator

\begin{tabular}{|c|c|c|c|c|c|c|c|c|c|c|}
\hline \multirow[t]{2}{*}{ Region } & \multicolumn{5}{|c|}{$C_{e 7}$} & \multicolumn{5}{|c|}{$C_{e 7 s}$} \\
\hline & 2008 & 2009 & 2010 & 2011 & 2012 & 2008 & 2009 & 2010 & 2011 & 2012 \\
\hline DolnoŜŃkie & $123,3 \%$ & $88,9 \%$ & $39,3 \%$ & $55,6 \%$ & $98,4 \%$ & $101,1 \%$ & $80,9 \%$ & $26,4 \%$ & $45,8 \%$ & $92,6 \%$ \\
\hline Kujawsko-pomorskie & $92,8 \%$ & $95,0 \%$ & $90,9 \%$ & $84,4 \%$ & $97,2 \%$ & $23,2 \%$ & $55,5 \%$ & $36,1 \%$ & $23,4 \%$ & $31,8 \%$ \\
\hline Lubelskie & $82,3 \%$ & $109,9 \%$ & $94,6 \%$ & $87,9 \%$ & $79,2 \%$ & $21,1 \%$ & $39,7 \%$ & $-8,0 \%$ & $31,1 \%$ & $14,1 \%$ \\
\hline Lubuskie & $109,5 \%$ & $95,6 \%$ & $83,4 \%$ & $98,0 \%$ & $94,8 \%$ & $27,1 \%$ & $73,5 \%$ & $29,4 \%$ & $39,5 \%$ & $21,3 \%$ \\
\hline Ğódzkie & $92,0 \%$ & $88,5 \%$ & $78,3 \%$ & $64,7 \%$ & $77,7 \%$ & $50,8 \%$ & $75,1 \%$ & $45,1 \%$ & $45,0 \%$ & $61,2 \%$ \\
\hline Mağpolskie & $101,6 \%$ & $91,7 \%$ & $79,0 \%$ & $87,8 \%$ & $99,4 \%$ & $81,7 \%$ & $80,4 \%$ & $65,2 \%$ & $78,1 \%$ & $81,2 \%$ \\
\hline Mazowieckie & $55,9 \%$ & $68,7 \%$ & $88,2 \%$ & $78,6 \%$ & $105,0 \%$ & $108,0 \%$ & $145,5 \%$ & $254,8 \%$ & $173,2 \%$ & $222,2 \%$ \\
\hline Opolskie & $119,1 \%$ & $85,9 \%$ & $76,1 \%$ & $86,6 \%$ & $102,0 \%$ & $71,9 \%$ & $63,6 \%$ & $39,8 \%$ & $49,7 \%$ & $44,2 \%$ \\
\hline Podkarpackie & $125,1 \%$ & $79,7 \%$ & $78,8 \%$ & $92,1 \%$ & $94,6 \%$ & $28,3 \%$ & $30,7 \%$ & $14,4 \%$ & $34,0 \%$ & $31,4 \%$ \\
\hline Podlaskie & $155,2 \%$ & $118,0 \%$ & $119,8 \%$ & $86,4 \%$ & $88,1 \%$ & $56,5 \%$ & $81,1 \%$ & $26,9 \%$ & $38,3 \%$ & $30,9 \%$ \\
\hline pomorskie & $113,1 \%$ & $86,5 \%$ & $61,5 \%$ & $82,2 \%$ & $91,2 \%$ & $89,3 \%$ & $75,3 \%$ & $38,5 \%$ & $63,1 \%$ & $73,1 \%$ \\
\hline ślŃkkie & $77,1 \%$ & $75,8 \%$ & $89,4 \%$ & $81,5 \%$ & $86,9 \%$ & $72,4 \%$ & $68,8 \%$ & $79,9 \%$ & $66,6 \%$ & $76,5 \%$ \\
\hline Świňtokrzyskie & $181,3 \%$ & $107,5 \%$ & $83,9 \%$ & $94,1 \%$ & $76,4 \%$ & $95,7 \%$ & $72,2 \%$ & $29,2 \%$ & $49,0 \%$ & $46,5 \%$ \\
\hline WarmiCkko-mazurskie & $147,2 \%$ & $92,6 \%$ & $88,7 \%$ & $89,4 \%$ & $78,8 \%$ & $32,7 \%$ & $46,2 \%$ & $-14,0 \%$ & $12,8 \%$ & $27,1 \%$ \\
\hline Wielkopolskie & $84,6 \%$ & $102,6 \%$ & $88,2 \%$ & $83,4 \%$ & $91,1 \%$ & $74,0 \%$ & $98,8 \%$ & $77,9 \%$ & $78,6 \%$ & $84,2 \%$ \\
\hline Zachodniopomorskie & $102,7 \%$ & $97,4 \%$ & $87,1 \%$ & $74,7 \%$ & $90,8 \%$ & $33,8 \%$ & $73,6 \%$ & $43,6 \%$ & $42,3 \%$ & $55,2 \%$ \\
\hline
\end{tabular}

Source: Own calculations based on MF (Ministry of Finance) and NSO (National Statistical Office) data

The last of the indicators under analysis is the so-called self-financing indicator, representing the share of own resources in the financing of regional investments(Ce7). For the majority of regions, this indicator, when adjusted by revenue from horizontal equalisation quotas, dropped considerably. In some cases, the drop was well below 100 percentage points. Increase was observed mainly for Mazovia $\ddot{i}$ in the absence of equalisation mechanisms, this region would surely profit from full liquidity of investment financing.

\section{Conclusions}

The main objective of this paper was to conduct the analysis and the assessment of the significance of a equalisation and regional part of the general subsidy for the voivodeships in Poland. In the majority of cases omitting the subsidy in the calculation resulted in the deterioration of the budgetary indicators in the half of voivodeships. It should be noticed that in the most extreme cases, the volume of subventions received was as much as twice the size of own revenue. This may attest to the striking maladjustment between the structure of regional income and the regional financing demands. It must be also noted that the outflow of proceeds under the pending óRobin Hood taxôregulations $i ̈$ in the case of the Mazovian Voivodship ï reached as much as a third of regional revenue, overall. This has the effect of greatly reducing the level of financing available for self-governing regions. In the Mazovian Voivodeship, the adopted fiscal solution resulted in liquidity loss. However, in the face of the present đ́Robin Hood taxô the Mazovian Voivodship found itself on the verge of bankruptcy last year, and refused to contribute, pending future development of the debate. To sum up, both the negative and positive effects of the horizontal equalisation mechanism can be demonstrated with respect to financial position of the regions in Poland.

\section{References}

[1] Act on the Regional Self-Government., Dz.U. 1998. 91.576

[2] Act on the Revenues of the Units of Territorial Self-government, Dz.U.2010.10.86

[3] Ministry of Finance. [online]. [cit. 2014-03-14]. Available at: <http://www.finanse.mf.gov.pl/budzetpanstwa/finanse samorzadow/opracowania>

[4] National Statistical Office, Local Data Bank. [online]. [cit. 2014-03-14]. <Available at www.stat.gov.pl/bdl/app/strona.html?p_name=indeks>

[5] OLEJNICZAK J., (1994). The Influence of the Equalisation Mechanism under the General Subsidy upon the Financial Situation of Communes as Exemplified by the Urban Communes of Lower Silesia Voivodeship ï Study Results. In Economic Development and Management of Regions, HED, Part V, pp.91-104, ISBN 978-80-7435-370-3. 
[6] The Act on Public Finances Dz.U.2009.157.1240

[7] European Charter of Regional Self-Government, adopted at the $4^{\text {th }}$ session of the Congress of Local and Regional Authorities of Europe., (1997) [online]. [cit. 2014-02-27]. Available at: <www.coe.int/t/dgap/localdemocracy/default_en.asp> 